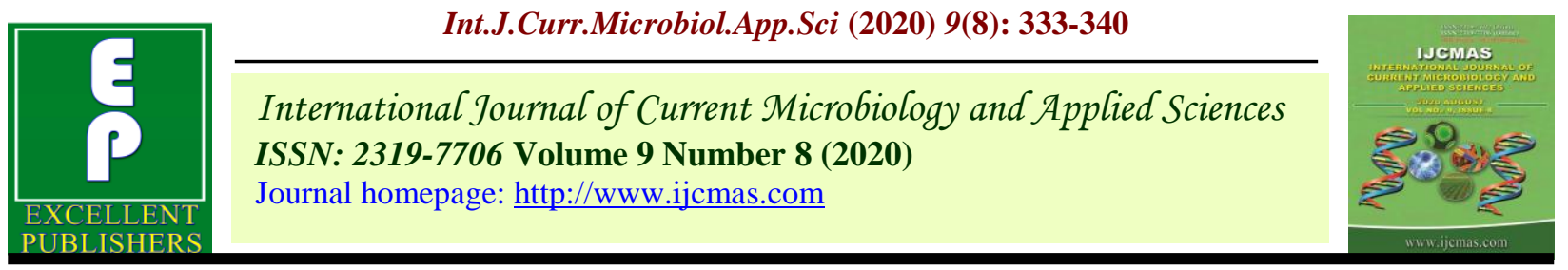

Original Research Article

https://doi.org/10.20546/ijcmas.2020.908.039

\title{
Evaluation of Pseudomonas fluorescence based Commercial Biopesticide Products against their Indicated Phytopathogens
}

\author{
Mehjebin Rahman", P. K. Borah and L. C. Bora \\ Department of Plant Pathology, Assam Agricultural University, Jorhat-785013, Assam, India \\ *Corresponding author
}

\section{A B S T R A C T}

\begin{tabular}{l} 
Ke y w or d s \\
$\begin{array}{l}\text { Biocontrol agents, } \\
\text { Inhibition } \\
\text { percentage, } \\
\text { Population count }\end{array}$ \\
Article Info \\
$\begin{array}{l}\text { Accepted: } \\
\text { 10 July 2020 } \\
\text { Available Online: } \\
\text { 10 August } 2020\end{array}$ \\
\hline
\end{tabular}

\begin{abstract}
The present investigation was conducted to evaluate some Pseudomonas fluorescence based commercial biopesticides marketed in Assam. Total six biopesticide products were evaluated. Both qualitative and quantitative assessments of the biopesticide products were carried out during the study. Quantitative assessment of the products revealed the presence of indicated bioagents only in three products: Commercial Biopesticide Products (CBP)-1, Commercial Biopesticide Products (CBP)-2 and Commercial Biopesticide Products (CBP)-3 with population count of $1.3 \times 10^{9}, 6.5 \times 10^{8}, 8.0 \times 10^{8} \mathrm{cfu} / \mathrm{ml}$ or $\mathrm{cfu} / \mathrm{gm}$, respectively. The three Pseudomonas fluorescens isolates were further qualititatively assessed in vitro for evaluating their efficacy against their indicated plant pathogens. $P$. fluorescens from Commercial Biopesticide Products (CBP)-3 was found most effective against Alternaria brassicae (85.50\%), from Commercial Biopesticide Products (CBP)-1 and Commercial Biopesticide Products (CBP)-2 against Fusarium oxysporum fsp lycopersicum $(80.00 \%)$ and Alternaria brassicae $(85.50 \%)$, respectively.
\end{abstract}

\section{Introduction}

Biopesticides are effective and biodegradable substance without any residues in the environment as compared to the synthetic pesticides which are the earliest and most common method used for controlling pests and diseases in plants. Biopesticides comprise only a small share (5.0 per cent) of the total crop protection market globally (Christos et al., 2018) and 4.2 per cent of the entire pesticide market in India (Gautam et al., 2018). Till recently, about 175 active ingredients and 700 products have been registered worldwide (Kachhawa, 2017). However, the use of biopesticides is increasing globally by approximately 10 per cent every year (Kumar and Singh, 2015). It seems that, if the global market increases further in the future, the biopesticides can play a vital role in substituting chemical pesticides reducing the current over-reliance on these ecologically harmful chemicals.

In India, since early nineties, microbial biopesticides have been produced by a good number of entrepreneurs which now counts to be around 400 . But, only 10 per cent of these production units have proper facility and rest of the 90 per cent biopesticides enterprises are run for short term gains which are mostly 'one-man-shows'. The later, do not have good 
facilities with regard to fermentation equipment, qualified microbiologists, trained staff, and sufficient space for operating each step of production, enough buffering capacity and rolling capital. Such enterprises with lack of proper infrastructure often end up with physical and biological contamination (Koul et al., 2012).

It is very difficult to produce biopesticides with constant purity like synthetic pesticides, which are produced in desired purity and yield. A wide variation occurs in the active and associated ingredients of the products if mishandled during processing and transporting. These lead to variation in the chemical, physiochemical, phytocompatibility, toxicological and other related properties of the products. However, the most important issue with the biopesticide products are contamination of the products with other microbial contaminants. The lack of proper standards and analytical procedures for manufacturing of these products and also poor shelf life of the bioagents in the products are the serious impediments in quality control of biopesticides (Isman, 2006). Quality control needs to be ensured at all levels of mass production of the nucleus culture (biocontrol agents) by taking extreme care in all the steps of production, i.e. isolation and preservation of the bioagents; storage, transportation and releasing techniques of the bioproducts.

In Assam, the scope of biopesticide industry can be visualized through the "Act East Policy' develop by the Govt of India. The border between North-East India and South Asian countries will be turned into a trade and business hub of South East Asia. This seems to be a potential boon for North East Indian growers to enter into the South East Asian market for trading of agricultural commodities and processed food products most specifically of organic origin. Biopesticides in the Agro-markets of Assam are manufactured by several commercial companies in different districts of the State. Besides, some biopesticide products are also imported from different states by these companies as per demand of the local growers.

Bacteria under genus Pseudomonas and Bacillus are the most promising biocontrol agents that have the abilities to act against wide range of phytopathogens. They suppress the disease causing activity of plant pathogenic microbes through several mechanisms like antibiosis, secretion of volatile toxic metabolites, mycolytic enzymes, parasitism and competition for food and space. Pseudomonas species, $P$. fluorescens, $P$. putida, P. cepacia produces antibiotics, viz., Pyrol, Nitrin, Oomycin-A and hormones such as Indole acetic acid (IAA), Gibberillic acid (GA) and Siderophores, that inhibit the growth of pathogens (Bhattacharjee et al., 2014).

\section{Materials and Methods}

Present investigation on Pseudomonas fluorescens biopesticides with special reference to evaluation of antagonistic activity of $P$. fluorescens against fungal pathogen were carried out in the Department of Plant Pathology, Assam Agricultural University, Jorhat (Assam).

For isolation, one gram of biopesticide sample was placed in a $250 \mathrm{ml}$ conical flask containing $100 \mathrm{ml}$ of sterilized distilled water (SDW) and mixed thoroughly. Different dilutions of working samples were prepared by serially diluting the stock solution upto $10^{-}$ ${ }^{8}$. One $\mathrm{ml}$ of last serial dilution i.e., $10^{-8}$ was spread on P. fluorescens selective King's B Medium (King's et al., 1954) for isolation of $P$. fluorescens. The plates were incubated for 2 days at $28 \pm 2^{\circ} \mathrm{C}$ and after incubation, pure culture was grown; colour of bacterial colony 
was initially yellow but turned yellow green as pigmentation were produced (Bonds, 1957). The numbers of colonies formed on each medium were counted at 48-72 hrs for bacteria and at $120 \mathrm{hrs}$ for fungi after incubation. Colony forming units (cfu) were calculated using the equation of Johnson and Case (2007).

\section{Colony forming Unit $(\mathrm{Cfu}) / \mathrm{gm}$ or Cfu/ml $=$ № of Colonies $\times$ Dilution Factor Aliquot taken (ml)}

The bioagents isolated were preserved for their further studies to evaluate the bioactive potential against plant pathogens.

\section{Culture and maintenance}

The medium consists of $20 \mathrm{gm}$ peptone, $20 \mathrm{gm}$ agar-agar, $1.5 \mathrm{gm}$ potassium monophosphate (K2HPO4), $1.5 \mathrm{gm}$ magnesium sulphate (MgSo4), glycerol $10 \mathrm{~mL}$ and distilled water $1000 \mathrm{~mL}$ (King et al., 1954). All the ingredients were mixed with distilled water homogenously. The media was then placed into a stainless steel pan and stirred with glass rod for proper mixing of all the ingredients. Now the medium was filtered through a muslin cloth by squeezing out whole liquid. $200 \mathrm{ml}$ medium was placed in each $500 \mathrm{ml}$ capacity flasks. These were tightly plugged with non-absorbent cotton plug and wrapped with butter paper and rubber band. Medium was autoclaved at $15 \mathrm{psi}\left(121.6^{\circ} \mathrm{C}\right)$ for $20 \mathrm{~min}$ and cooled before pouring into Petri plates. Another medium contain agar-agar $20.0 \mathrm{~g}$, dextrose $20.0 \mathrm{~g}$, potato (peeled and sliced) $200.0 \mathrm{~g}$, distilled water $11.250 \mathrm{~g}$ of potato was peeled and cut into small and fine sliced pieces. Exactly $200 \mathrm{~g}$ of potato pieces were weighed and placed into a stainless steel pan. $500 \mathrm{ml}$ of water was added to potato pieces and boiled gently for such a period until they were easily mashed by a glass rod. The decoction was filtered through muslin cloth and squeezed out all the liquid in a measuring cylinder and potato pieces were discarded.
Now, sufficient amount of water was added to make the volume $1000 \mathrm{ml}$. The preweighed agar agar was added $(20 \mathrm{~g})$ bit by bit to the boiling solution to dissolve it. At the same time dextrose $(20 \mathrm{~g})$ was also added in boiling solution (melted with agar) and final volume made up to 11 . It was poured at about $200 \mathrm{ml}$ in each of four conical flasks of $500 \mathrm{ml}$ and 10 $\mathrm{ml}$ per culture tube to prepare the PDA slants. Both, flasks and culture tubes were tightly plugged with nonabsorbent cotton and wrapped with butter paper and rubber bands.

The culture tubes and flasks were placed vertically (mouths up) in wire baskets and then autoclaved at $15 \mathrm{psi}\left(121.6^{\circ} \mathrm{C}\right)$ for 20 min. The bacteria, initially isolated in a pure culture on King's B media and sub cultured on PDA slants were allowed to grow at $28 \pm 20^{\circ} \mathrm{C}$ temperature. The culture thus obtained was stored in refrigerator at $50^{\circ} \mathrm{C}$ for further studies and was sub cultured periodically.

\section{Antagonism of $\boldsymbol{P}$. fluorescens}

The antagonistic activity of $P$. Fluorescens against Foc, Alternaria sp., Colletotrichum $\mathrm{sp}$, . Rhizoctonia solani and Sclerotium rolfsii were tested by dual culture technique. For evaluation of $P$. fluorescens inhibition efficacy against the fungal pathogens, $5 \mu \mathrm{l}$ of bacterial suspension $\left(10^{8} \mathrm{cfu} / \mathrm{ml}\right)$ was placed on the four sides of the plate. After $48 \mathrm{hrs}$ incubation at $28 \pm 2{ }^{\circ} \mathrm{C}$, a $6 \mathrm{~mm}$ diameter mycelial disc was placed at the center of plates. Then, plates were incubated at $28 \pm 1^{\circ} \mathrm{C}$ for 7 days. The growth diameter of the pathogen (distance between the point of placement of fungal disk and actively growing edges of the fungus) was measured. The percentage of growth inhibition was calculated according to Erdogan and Benlioglu (2010) method. This experiment was conducted thrice. 
Per cent inhibition $(\mathrm{I})=\mathrm{C}-\mathrm{T} / \mathrm{C} \times 100$

Where,

C- mycelial growth of pathogen in control

$\mathrm{T}$ - mycelial growth of pathogen in dual culture plate.

\section{Results and Discussion}

\section{Isolation of $\boldsymbol{P}$. fluorescens}

Six biopesticides indicating the presence of $P$. fluorescens were assessed. On the basis of colony characteristics and pigmentation etc, only three isolates were confirmed to be $P$. fluorescens isolated from three biopesticide products and tested against Fusarium oxysporum f.sp. lycopersici, Rhizoctonia solani, and Alternaria brassicae, Sclerotium rolfsii, Colletotrichum gloesporoides.

The three Pseudomonas fluorescens isolates isolated and confirmed as Pseudomonas fluorescens during present investigation were designated as given below:

\begin{tabular}{|l|l|}
\hline $\begin{array}{l}\text { Pseudomonas } \\
\text { fluorescens isolates }\end{array}$ & Biopesticide Product \\
\hline Pf 1 & $\begin{array}{l}\text { Commercial Biopesticide } \\
\text { Products (CBP)-3 }\end{array}$ \\
\hline Pf2 & $\begin{array}{l}\text { Commercial Biopesticide } \\
\text { Products (CBP)-1 }\end{array}$ \\
\hline Pf3 & $\begin{array}{l}\text { Commercial Biopesticide } \\
\text { Products (CBP)-2 }\end{array}$ \\
\hline
\end{tabular}

\section{Dual culture technique}

The results of the dual culture technique indicated that the three isolates inhibited growth of tested fungi significantly. In case of Fusarium oxysporum f.sp. lycopersici a maximum inhibition of $84.80 \%$ was recorded by Commercial Biopesticide Products (CBP)2 and minimum of $76.20 \%$ was recorded with the isolate Commercial Biopesticide Products (CBP)-3. In case of Alternaria brassicae, the maximum inhibition of $85.50 \%$ was exhibited by Commercial Biopesticide Products (CBP)-
207 and minimum, $70.20 \%$ was recorded with the Commercial Biopesticide Products (CBP)-1 isolate, where as in case of Colletotrichum gloeosporoides maximum inhibition $84.80 \%$ was recorded by Commercial Biopesticide Products (CBP)-2 and minimum, $63.70 \%$ was recorded with isolate Commercial Biopesticide Products (CBP)-3. Again, in case of Rhizoctonia solani and Sclerotium rolfsii highest inhibition was recorded to be $40.00 \%$ and $77.70 \%$ respectively by Commercial Biopesticide Products (CBP)-2 and lowest was recorded $26.00 \%$ and $60.00 \%$ respectively by Commercial Biopesticide Products (CBP)-3. (Plate 2, Table 2, Fig 1).

With the aim to help the local growers and farmers of Assam to facilitate with quality bio inputs which in turn may augment in their strategy of organic conversion of their farmland and products, and also to help them in exporting their quality proven products, the present research programme has been conceived. In this direction six Pseudomonas fluorescens biopesticides were isolated on King's B medium and further they were subjected to identification on the basis of antagonistic characteristics exhibited against some pathogenic microflora. Out of six biopesticides isolated on King's B medium, only three were confirmed as Pseudomonas fluorescens. The isolate Pf1 was isolated from Commercial Biopesticide Products (CBP)-3 biopesticide product while the isolate $\mathrm{Pf} 2$ was isolated from Commercial Biopesticide Products (CBP)-1 biopesticide product of Tropical Agro and isolate Pf3 from Commercial Biopesticide Products (CBP)-2.

A similar work was also done by All India Co-ordinated Project on Biological Control, Bangaluru and they have also reported that a very low level of active bioagents wrre present in the tested commercial biopesticide products. 
Table.1 Quantitative characteristics of evaluated biopesticide products

\begin{tabular}{|c|c|c|}
\hline Name of products & Active bioagents & Population (cfu/ml or gm) \\
\hline Commercial Biopesticide Products (CBP)-1 & Pseudomonas fluorescens & $1.3 \times 10^{9}$ \\
\hline Commercial Biopesticide Products (CBP)-2 & Pseudomonas fluorescens & $6.5 \times 10^{8}$ \\
\hline Commercial Biopesticide Products (CBP)-3 & Pseudomonas fluorescens & $8.0 \times 10^{8}$ \\
\hline
\end{tabular}

Fig.1 Comparative efficacy of different biopesticides against the targeted pathogens

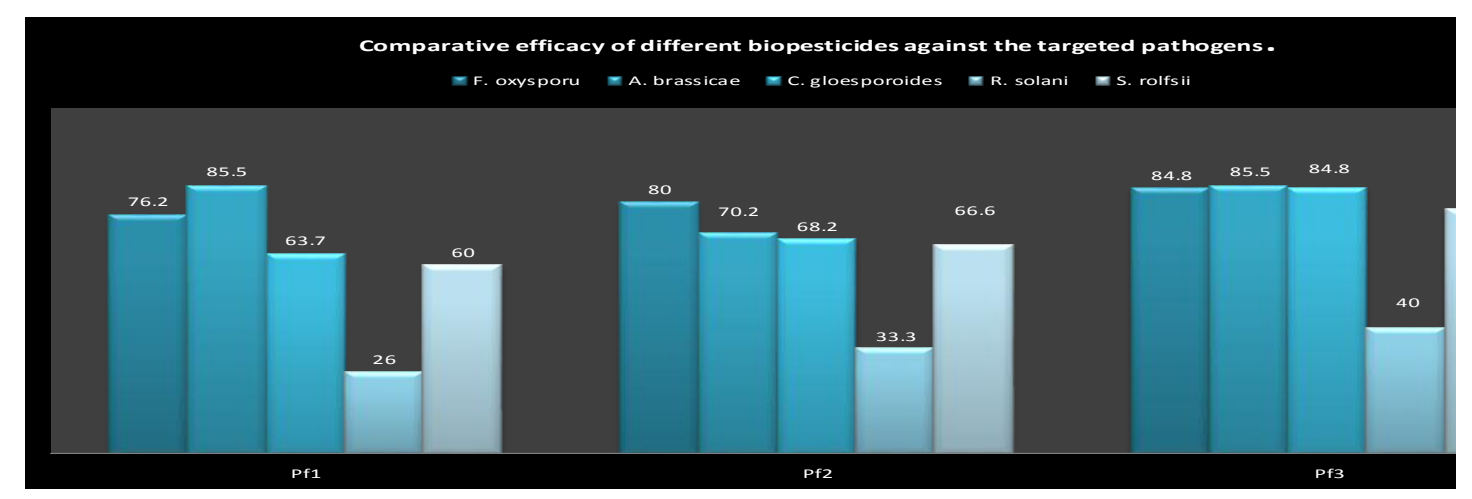

Plate.1(a-c) Colony forming units of Pseudomonas fluorescens from a) Commercial Biopesticide Products (CBP)-1, b)Commercial Biopesticide Products (CBP)-3, c) Commercial Biopesticide Products (CBP)-2
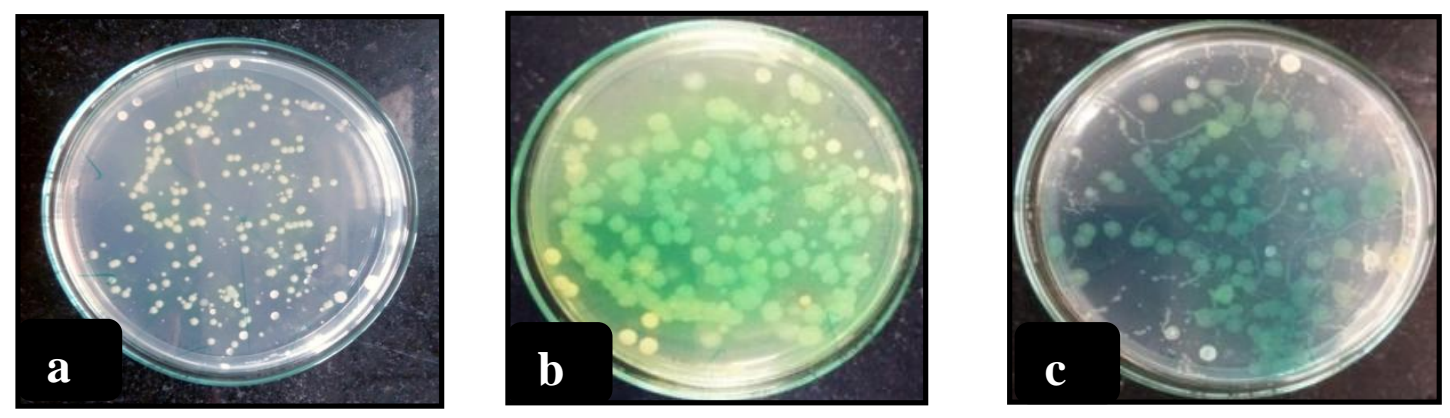
Table.2 Antagonistic activity of Pseudomonas fluorescens against indicated fungi

\begin{tabular}{|c|c|c|c|}
\hline $\begin{array}{c}\text { Pseudomonas } \\
\text { fluorescens Isolates }\end{array}$ & Test Fungi & Mycelial growth (mm) & Growth inhibition (\%) \\
\hline Pf1 & \multirow{3}{*}{$\begin{array}{l}\text { Fusarium oxysporum } \\
\text { fsp. lycopersici }\end{array}$} & 10.70 & $76.2(60.80)$ \\
\hline Pf2 & & 9.00 & $80.0(63.43)$ \\
\hline Pf3 & & 6.80 & $84.8(67.05)$ \\
\hline \multicolumn{2}{|l|}{ S.Ed ( \pm$)$} & & 0.32 \\
\hline \multicolumn{3}{|l|}{$\mathrm{CD}_{0.05}$} & 0.66 \\
\hline Pf1 & \multirow[t]{3}{*}{ Alternaria brassicae } & 14.70 & $85.5(67.72)$ \\
\hline Pf2 & & 13.4 & $70.2(56.91)$ \\
\hline Pf3 & & 6.50 & \multirow{2}{*}{$\begin{array}{l}85.5(67.62) \\
0.59\end{array}$} \\
\hline \multicolumn{3}{|l|}{ S.Ed ( \pm$)$} & \\
\hline \multicolumn{3}{|l|}{$\mathrm{CD}_{0.05}$} & 1.22 \\
\hline Pf1 & \multirow{3}{*}{$\begin{array}{l}\text { Colletotrichum } \\
\text { gloesporoides }\end{array}$} & 16.30 & $63.7(52.95)$ \\
\hline Pf2 & & 14.30 & $68.2(55.67)$ \\
\hline Pf3 & & 6.80 & $84.8(67.05)$ \\
\hline \multicolumn{3}{|l|}{ S.Ed $( \pm)$} & 0.46 \\
\hline \multicolumn{3}{|l|}{$\mathrm{CD}_{0.05}$} & 0.95 \\
\hline Pf1 & \multirow{3}{*}{ Rhizoctonia solani } & 33.00 & $26.0(30.66)$ \\
\hline Pf2 & & 30.00 & $33.3(35.24)$ \\
\hline Pf3 & & 27.00 & $40.0(39.23)$ \\
\hline \multicolumn{3}{|l|}{ S.Ed $( \pm)$} & 1.94 \\
\hline \multicolumn{3}{|l|}{$\mathrm{CD}_{0.05}$} & 4.01 \\
\hline Pf1 & \multirow[t]{3}{*}{ Sclerotium rolfsi } & 18.00 & $60.0(50.77)$ \\
\hline Pf2 & & 15.00 & $66.6(54.70)$ \\
\hline Pf3 & & 10.00 & $77.7(61.82)$ \\
\hline \multicolumn{2}{|l|}{ S.Ed ( \pm ) } & & 1.08 \\
\hline \multicolumn{3}{|l|}{$\mathrm{CD}_{0.05}$} & 2.23 \\
\hline
\end{tabular}

( ): Arcsine transformation value 
Plate.2 a) Control plate of $F$. oxysporum f.sp. lycopersici, b) Control plate of $A$. brassicae, c) Control plate of $C$. gloeosporoides, d) Control plate of $R$. solani, e) Control plate of S. rolfsii, a') $F$. oxysporum f.sp. lycopersici in presence of $P$. fluorescens from Commercial Biopesticide Products (CBP)-2 product, $\mathrm{b}^{\prime}$ ) A. brassicae in presence of $P$. fluorescens from Commercial Biopesticide Products (CBP)-2 product, $\left.\mathrm{c}^{\prime}\right) C$. gloeosporoides in presence of $P$. fluorescens from Commercial Biopesticide Products (CBP)-2 product, $\left.\mathrm{d}^{\prime}\right) R$. solani in presence of $P$. fluorescens from Commercial Biopesticide Products (CBP)-2 product, e') $S$. rolfsii in presence of $P$. fluorescens from Commercial Biopesticide Products (CBP)-2 product.
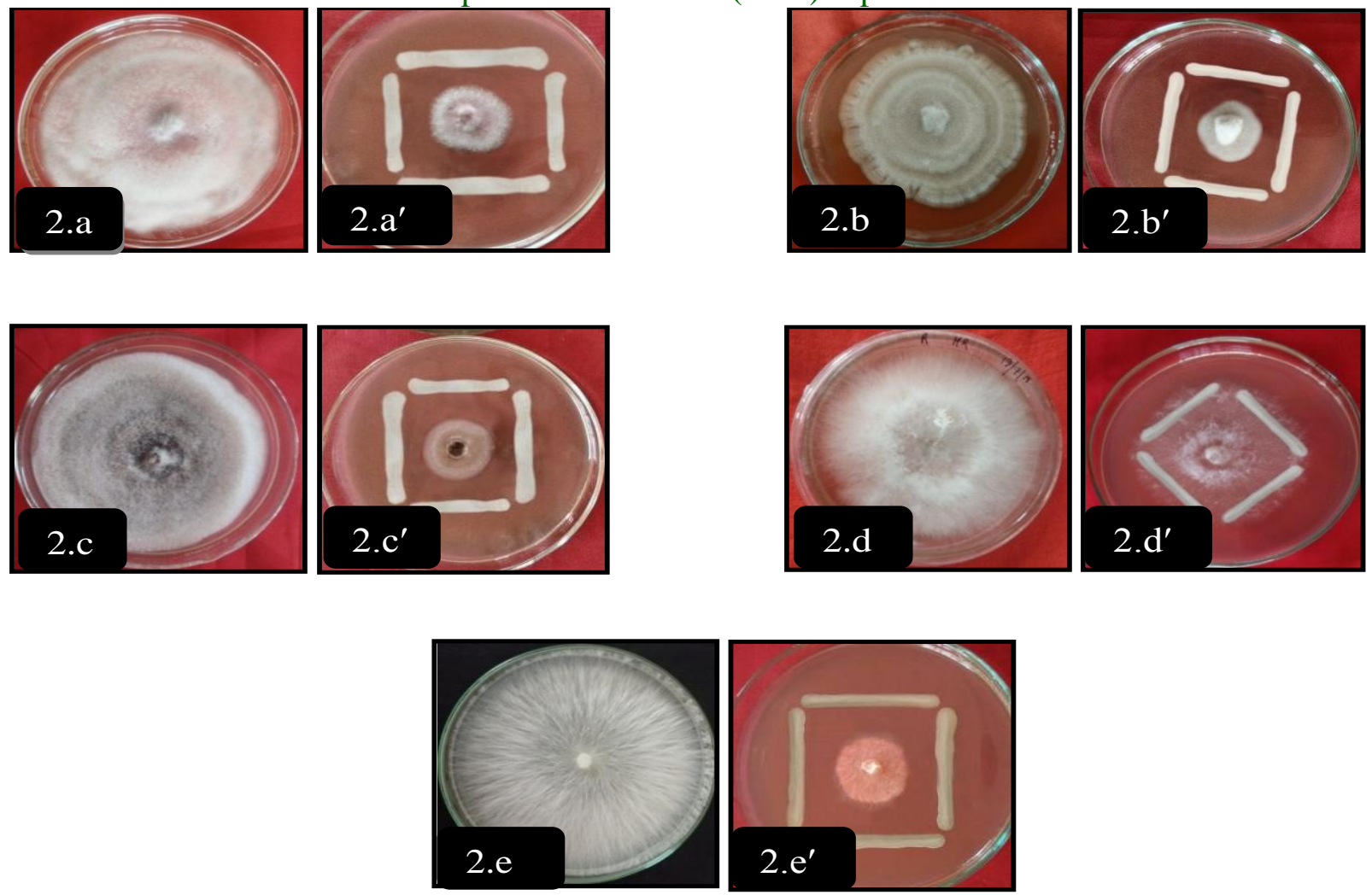

The results of the dual culture technique indicated that the three isolates were able to inhibit growth of tested fungal pathogen significantly. In case of $F$. oxysporum f.sp lycopersici a maximum and minimum inhibition was exhibited by Pf3 $(84.80 \%)$ and Pf1 (76.20\%) respectively. In case of Alternaria brassicae, the maximum inhibition of $85.50 \%$ was exhibited by Pf1 and Pf3 and minimum, $70.20 \%$ was exhibited by Pf2 where as in case of Colletotrichum gloesporoides maximum inhibition $84.80 \%$ was exhibited by Pf3 and minimum, 63.70\% was exhibited with isolate Pf1. Again in case of Rhizoctonia solani and Sclerotium rolfsii the maximum inhibition were $40.00 \%$ and $77.70 \%$ respectively exhibited by $\mathrm{Pf} 3$ and minimum were $26.00 \%$ and $60.00 \%$ by Pf1 respectively. Wagner et al., (2018) suggested that fluorescent pseudomonads had antagonistic effect that was not necessarily associated with the production of antibiotics. Several reports on plant-associated pseudomonads indicated also a role of siderophores, lytic enzymes, hydrogen cyanide and ammonia as well as organic volatiles in the inhibition of fungal phytopathogens.

From the present study, it is found that most 
of the biopesticide products do not retain the indicated bioagents. Some of them also contained microbial contamination at a high amount. A good infrastructure, a proper supply chain for nucleus cultures and a stable ecosystem with required temperature and humidity should be established to maintain the quality of products. A number of characteristics are desirable for the biocontrol agent to become commercial reality. Strong synergies between Ministry of Agriculture, Govt of India, CIPMCs, State Agriculture Departments, SAUs and ICAR Institutes, Private Biopesticides Industries, KVKs, NGOs etc. need to be developed to attain the overall goal of promotion of biopesticides. Certain quality issues like the original and true to type of biocontrol strains, efficacy, minimum spore concentration, physical parameters of formulated products and free from contaminants and chemical pesticides are of paramount importance for the registration of biopesticides. The quality of biopesticides should not be compromised at any cost during production and storage for ensuring the supply of authenticated products to the farmers.

\section{References}

Bhattacharjee, R. and Dey, R. 2014. An overview of fungal and bacterial biopesticides to control plant pathogens/diseases. Afr. J. Microbiol. Res. 8(17):1749-1762
Bonds, G. J., Jensen, C.E. and Thamasen, J. 1957. A water soluble fluorescing bacterial pigment which deplomerize hylorenic acid. Acta Pharmocol, Toxicol, 13: 184-193.

Christos, A. Damalas, I.D. and Spyridon, D. K. 2018. Current Status and Recent Developments in Biopesticide Use. Agric. 2018, 8(13): 67-94

Gautam, N.K. Kumar, A and Singh V.K. 2018. Bio-Pesticide: A clean approach to healthy agriculture. Int.J.Curr.Microbiol.App.Sci 7(3): 194197

Isman, M.B. 2006. Botanical insecticides, deterrents, and repellents in modern agriculture and an increasingly regulated world. Annu.Rev.Entomol. 51: 45-66.

Johnson, L.E. and E.A. Curl. 1972. Methods for research on the ecology of soilborne plant pathogens. Minneapolis: Burgess Publishing Co.

Kachhawa D. 2017. Microorganisms as a biopesticides. J. Entomol. Zool. Stud. 5(3):468-473

Koul, O.; S. Dhaliwal, G.; Sucheta, K. and Singh, R. 2012. Biopesticides in Environment and Food Security: Issues and strategies.

Kumar, S. and Singh, A. 2015. Biopesticides: Present status and the future prospects. J. Fertil Pestic.6:2

\section{How to cite this article:}

Mehjebin Rahman, P. K. Borah and Bora, L. C. 2020. Evaluation of Pseudomonas fluorescence based Commercial Biopesticide Products against their Indicated Phytopathogens. Int.J.Curr.Microbiol.App.Sci. 9(08): 333-340. doi: https://doi.org/10.20546/ijcmas.2020.908.039 